\title{
A GEOMETRICAL SIMILARITY PATTERN AS AN EXPERIMENTAL MODEL FOR SHAPES IN ARCHITECTURAL HERITAGE: A CASE STUDY OF THE BASE OF THE PILLARS IN THE CATHEDRAL OF SEVILLE AND THE CHURCH OF SANTIAGO IN JEREZ, SPAIN
}

\author{
J. J. Moyano ${ }^{\text {a }}$, J. A. Barrera ${ }^{\text {b }}$, J. E. Nieto ${ }^{\text {a }}$, D. Marín ${ }^{\text {a }}$, D. Antón ${ }^{\text {a }}$
}

${ }^{a}$ Dept. of Graphic Expression and Building Engineering, Higher Technical School of Building Engineering, University of Seville. 4A Reina Mercedes Avenue, 41012, Seville, Spain - (jmoyano, jenieto, damar, danton)@us.es

${ }^{\mathrm{b}}$ Dept. of Graphic Engineering, Higher Technical School of Building Engineering, University of Seville. 4A Reina Mercedes Avenue, 41012, Seville, Spain - barrera@us.es

\section{Commission II}

KEY WORDS: Geometrical similarity pattern, 3D range scanning, Terrestrial laser scanning, Structure-from-motion, 3D data comparison, Cathedral of Seville

\begin{abstract}
:
This paper proposes a procedure for the search of a geometrical similarity pattern in architectural heritage by means of calculating probability indexes to support hypotheses initially endorsed by documentary sources. The buildings analysed are the Cathedral of Seville and the Church of Santiago, in Jerez, Spain. The 3D models of their selected pillars are obtained by means of Terrestrial Laser Scanning (TLS), Optical Scanning (OS) and photogrammetry through image-based modelling software (SFM-IBM). To this end, a procedure for the comparison of shapes is established. It is based on similarity statistics, the determination of homologous points and the agreement of characteristic sections. Here, two key aspects are considered: on the one hand, the metric standpoint; on the other hand, historical-graphical features of the 3D models: composition, techniques, styles, and historical-graphical documentary sources. Thus, putting aside the mere dimensional analysis, the sections are compared with graphical patterns and models of which the same authorship - stonemasons working in that age - is accurately known. As a result, the outcomes of this research reveal the geometrical similarity between the elements of the pillars of the Cathedral of Seville and the Church of Santiago.
\end{abstract}

\section{MANUSCRIPT}

\subsection{Literature review}

The new technologies for data acquisition allow agents involved in restoration projects for architectural and cultural heritage to apply algorithms of analysis and vision, which enable high quality $3 \mathrm{D}$ modelling procedures. Nowadays, there are a large number of publications in which the photogrammetric Structure-From-Motion (SFM) technique and Terrestrial Laser Scanning (TLS) are employed in fieldwork so as to obtain precise data of the heritage (Pieraccini et al., 2001), (Yastikli, 2007), (Pavlidis et al., 2007), (Yilmaz et al., 2007), (Mostaza et al., n.d.), (Mañana-Borrazás et al., 2008), (Almagro, 2000), (Muñoz et al., 2010) and (Pérez-García et al., 2011). In this line and considered as advances towards the scientific development in the field of 3D modelling, other studies address superficial analysis methods to compare the reliability of both techniques (Teza et al., 2016), (Koutsoudis et al., 2014), (Westoby et al., 2012), or carry out the review of the use of different algorithms used for point cloud generation (Remondino et al., 2012).

The complex geometry of historic buildings, together with a large amount of ornamental elements in them, such as columns, capitals, domes, parapets, tiling and other architectural details, make it necessary to utilise the aforementioned technologies of massive capture. These precise technologies are complementary to Building Information Modelling (BIM) applied to cultural heritage (Nieto et al., 2014). There are plenty of studies that examine the texture of architectural design arrangements and the relationship between their surface by means of fractal pattern techniques (Herrera and Samper, 2014). Nevertheless, in practice it is a metric-characterised geometrical analysis that does not comply with the scope of this research.

Other enquiries compare the 3D models obtained by means of TLS and SFM with antique drawings. The idea is to examine the global dimensional accuracy and general appropriateness of the shapes in the drawings by different authors of the end of the XVIII and the XIX centuries (Fiorillo et al., 2013). There is also a computerised geometrical analysis of architectural heritage which focuses on the techniques applied to geometries in the field of cultural heritage. The review shows a vast scientific literature directed to experts in archaeology and history (Pintus et al., 2016).

In addition to the epistemology with regards to the comparative analysis of capture and representation techniques, the analysis of shapes of similar elements along the history of architecture is one of the questions addressed in diverse humanistic and historical texts. For instance, Pintus et al. (2016) deal with the analysis of shapes, geometrical descriptors and equity of shapes. However, this is not completely solved in technical-scientific literature. The assignment of the authorship of architectural structures is not solved in some cases due to the lack of documentary sources. In this sense, the usage and analysis of

\footnotetext{
* Corresponding author
} 
new technologies may shed light on numerous enquiries concerning the authorship of works.

\subsection{Objective}

This paper proposes a procedure for the search of a geometrical similarity pattern in architectural heritage by means of calculating probability indexes to support hypotheses initially endorsed by documentary sources. The 3D models of their selected elements in the samples of architectural heritage are obtained by means of Terrestrial Laser Scanning (TLS), Optical Scanning (OS) and photogrammetry through image-based modelling software (SFM-IBM). To this end, a procedure for the comparison of shapes is established. It is based on similarity statistics, the determination of homologous points and the agreement of characteristic sections.

\section{DATA ACQUISITION}

\subsection{Control points arrangement}

The arrangement of control points in measurements for architectural heritage is a deeply addressed matter in the scientific community. It has an extensive use in topography, terrestrial analysis, and architecture, aimed at achieving level and oriented models. One of the studies that analyses the control points defends their usage in structure monitoring (Arias et al., 2005). Concerning the terrestrial photogrammetry, Forlani et al., (2014) reveal the difficulty in arranging control points for georeferencing, likewise Dos Santos et al. (2013) review the scientific literature as regards the advantages of direct georeferencing in point cloud achievement for complex elements and geometries. For their part, Devrim Akca et al. (2010) address the verification of the data used by means of quality control in $3 \mathrm{D}$ modelling.

\subsection{D scanning}

The control points arranged in this paper already exist in the buildings studied and the surrounding pavements. These points were used to georeferenced the scans to the city plans by means of a total station.

Provided that the column bases scanned contain surfaces with sufficient geometrical magnitude, it was not necessary to set targets to connect the different scans. TLS was the technique used for this purpose: a Leica ScanStation C10 laser scanner with $5 \mathrm{~mm}$ resolution and $2 \mathrm{~mm}$ accuracy (in accordance with Leica Geosystems specifications). Two recordings were done on each side of the columns: one with high-resolution and another one with low accuracy to obtain the overlapping areas.

The detailed scanning of the base elements was then carried out by means of the handheld Artec MHT 3D scanner, after calibration according to the light conditions of the work place. The device has been used at a distance of approximately $0.70 \mathrm{~m}$, controlled in real time by the histogram of Artec Studio 10 Professional software. With a near linear field of view of 214 $\mathrm{mm} \times 148 \mathrm{~mm}$ (high x width) and distant $536 \mathrm{~mm} \mathrm{x} 371 \mathrm{~mm}$, the scanner provides a resolution of $1 \mathrm{~mm}$ for the creation of three-dimensional meshes that can also be textured, all recorded with up to a frame rate of 15 frames per second. The collection of data has been conducted by single scans per element in order to avoid alignment errors of their parts.
The resulting meshes have been finally aligned and located in their exact location on the global point clouds of each base. This process has been performed by visual orientation in plan and elevation. Illustrating the result of this process are shown in Figures 1 and 2.
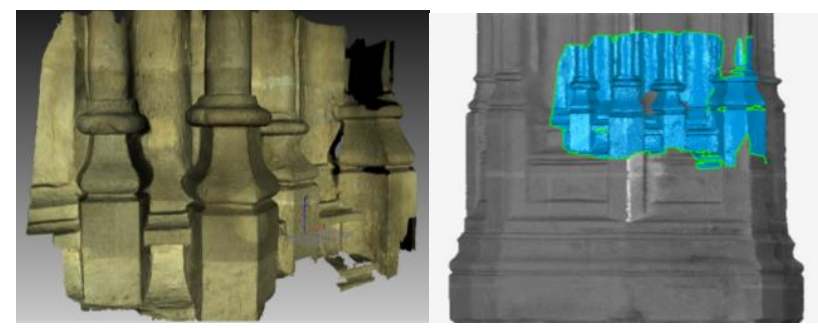

Figure 1. OS mesh placed on TLS point cloud (Church of Santiago)

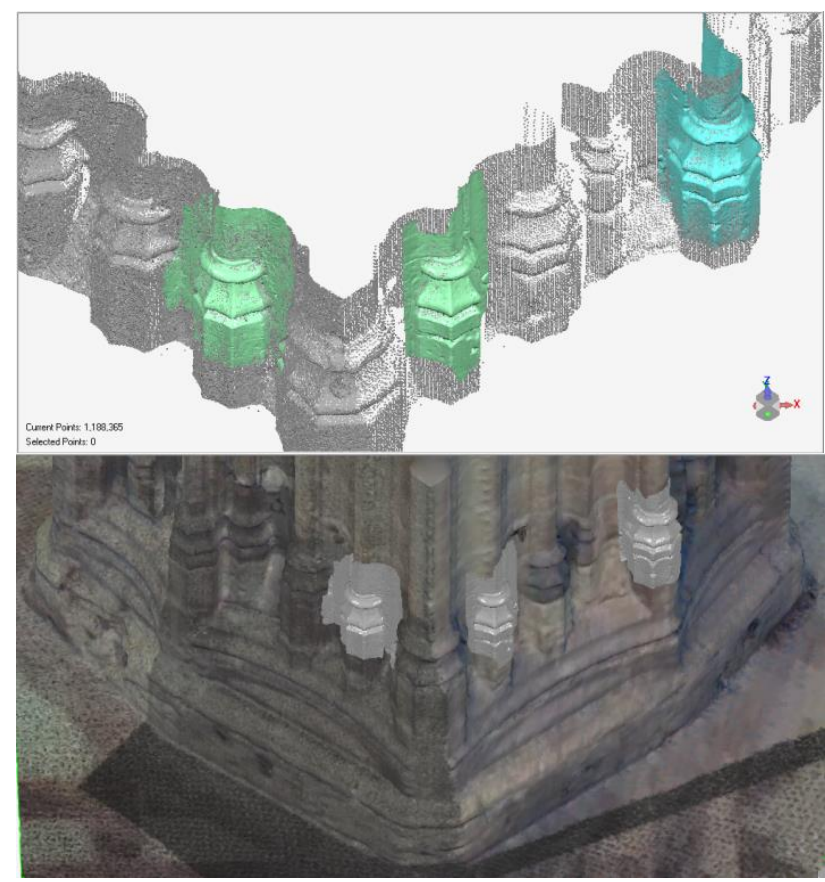

Figure 2. OS mesh placed on TLS point cloud (Cathedral of Seville)

\section{HISTORICAL DATA AND COMPARISON}

\subsection{The historiography of the stone cut and geometrical analysis of gothic shapes}

In the medieval Spanish historiography the study of cuts of stonework is well studied in the treatises made by: Hernán Ruiz el Joven; Alonso de Vandelvira; Ginés Martínez de Aranda; Cristóbal de Rojas; Alonso de Guardia; Pedro de Álbiz; Francois Derand; and others. These are treatises that express graphically the construction shapes of late-Gothic and Renaissance characterised architectures that were published from the XVI onwards. These Gothic shapes were used by architects in Baroque times (Vallejo, 2015), reason why they have lasted for many centuries. Most of the analyses deal with the interpretation of ancient treatises as regards regular tracings of domes, staircases, and studies of stonework. Matthäus Roriczer's notebooks are worth mentioning, since they were 
extensively studied by Presas i Puig (1997), and other researches (Rabasa, 2005) which analysed the geometry of stonemasons' paths under inspired geometric methods in the books of Viollet-Le-Duc (1854-1868).

Nowadays, one of the researchers in the analysis of the geometry of sections of Gothic traces is Capilla Tamborero (Capilla Tamborero, 2016), who establishes a series of hypotheses on the geometry of the sections of ribbed vaults of the Monastery of Santa Maria de la Valldigna (Valencia) based on Euclidean geometry of circles and triangles. This base of studies has its origin in the works of Professor Ruiz de la Rosa (1987), who has dedicated his research work in the study of the templates used to build the Cathedral of Seville (Ruiz de la Rosa, 2006), (Ruiz de la Rosa and Rodríguez Estevez, 2011). Other studies propose theoretical models based on topographic surveys to configure top-view geometries in domes (Cabeza González, 2013) and (Rabas Díaz, 1994) or documentation methods and analysis of full scale architectural designs (Calvo López, 2015).

In the process of the stonework (Molina Gaitán, 2011), it is documented that in the XVI century the cutting took place in a workshop located on site at the cathedral, requiring a previous full scale template. On the basis of Rabasa's work, Calvo López (1990) raises different solutions in the ways of extracting the stone, as "cutting by bevel or direct procedure", which represents in true magnitude the faces of the pieces. Generally these stencils were made of wood or another material such as iron.

In the literature on traces and geometry of the stone, it is established that the lines were the reference to control the construction process (Ana López Mozo et al., 2011). At that time the surface or the volume could not be represented by graphic means without interpretation of the sections and the contours. The geometric control of the shapes, traces, proportions, and curvatures or scale, can only be made from cuts, fundamentally horizontal or vertical. The aim of this researcher was to prove that some classic domes were almost exclusively erected over a line-based geometry in space rather than curves. In historical construction processes, points and lines can be represented with traces and verifiable on site, while surfaces are only accessible by intermediation of the layout and the control of their points and lines.

The reason why the geometrical control of the characteristic points studied in this paper is essential to design a pattern of geometrical similarity justifies the inference hypothesis.

Nowadays, as occurred in the past, the stonemasons verify the cutting of the stone through various instruments such as templates, rules, rigid or articulated set squares, and curved rules. In the stonework, the geometrical shape is inseparable from the structural function (Fernández-Sala, 1996). Therefore, building with stone is essentially the art based on the geometrical traces.

\subsection{Case study}

The Cathedral of Seville and the Church of Santiago in Jerez de la Frontera (Cádiz, Spain) have been taken as a case study for this research. The Church of Santiago is a late-Gothic structure of three naves. The style of this church is called cathedral Gothic due to the influence of the Cathedral of Seville (Caramazana and Romero, 2016). Sancho de Sopranis (1934) assigned the authorship of the traces of this church to the master builder of the Cathedral of Seville between 1496 and 1511, Alonso Rodríguez. Sancho de Sopranis also associated this master with the construction of the Priory of El Puerto de Santa María (Spain), given the fact that this building is closely related to the buildings studied in this paper. Márquez (1986) assures "that the Church of Santiago is the most direct inheritance of the Cathedral of Seville" (Sic). In both buildings similarities can be found in the highly developed and isolated apse that both churches possess: the absence of a transept; the rhomboidalsection pillars; and the richness of the decoration in façades. There are also correspondence relating to the blind windows of the apse (today open in the Church of Santiago) and in the canted arches of the perimeter walls. Alonso Rodríguez worked in the closing of the primitive dome and the naves of the eastern side (Ortiz de Zúñiga, 1895) of the cathedral. During his work in Seville, the master designed the traces of the Church of Santiago, but the authorship hypothesis is a current issue in the scientific community in favour of other masters of the XVII century.

As displayed in Figure 3, the first pillar of the retrochoir in both churches was selected to be analysed.

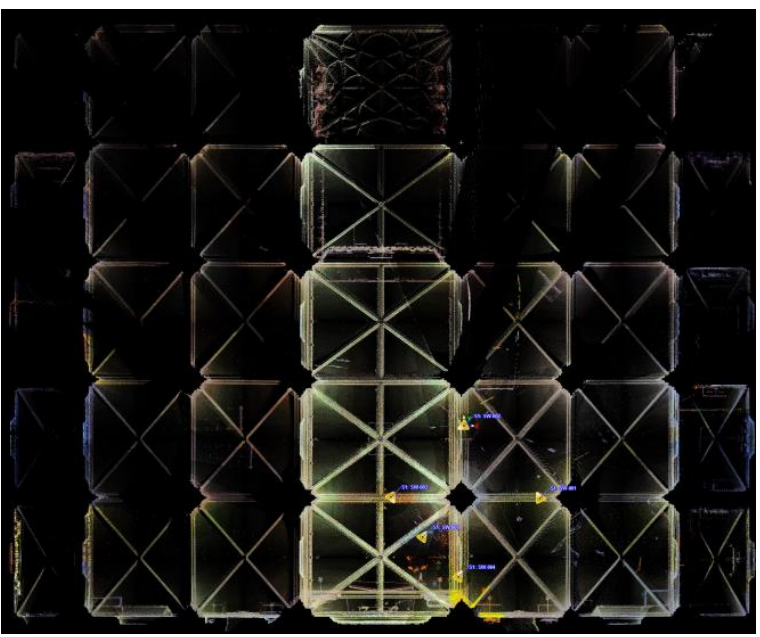

Figure 3. Top view of the ceiling in the Cathedral of Seville, taken using TLS

\section{DATA PROCESSING}

\subsection{Methodology}

The proposed methodology is based on establishing the characteristic points of the geometrical shapes of the pillar bases in the Cathedral of Seville and the Church of Santiago. They are compared with graphical patterns and models of which the same authorship of the stonemasons who worked at that time is accurately known. This will determine the creation of patterns by stonemasons in both churches. The original points are analysed and the matching points of the other case are determined.

By following this methodology, two key aspects are considered: on the one hand, the metric standpoint; on the other hand, historical-graphical features of the 3D models. Although there are diverse experiences, ad-hoc algorithm proposals and point cloud comparison techniques (Mémoli et al., 2005), it was decided to choose a more than enough tested software package, 
which is useful for management and comparison of point clouds: CloudCompare (Rajendra et al., 2014).

The accuracy of the instruments utilised and the optimisation of characteristic points by means of the mean squared error (De Reu et al., 2013) were empirically taken into consideration. A sample of the points and the sections of the elements in the Cathedral of Seville are displayed in Figures 4 and 5.
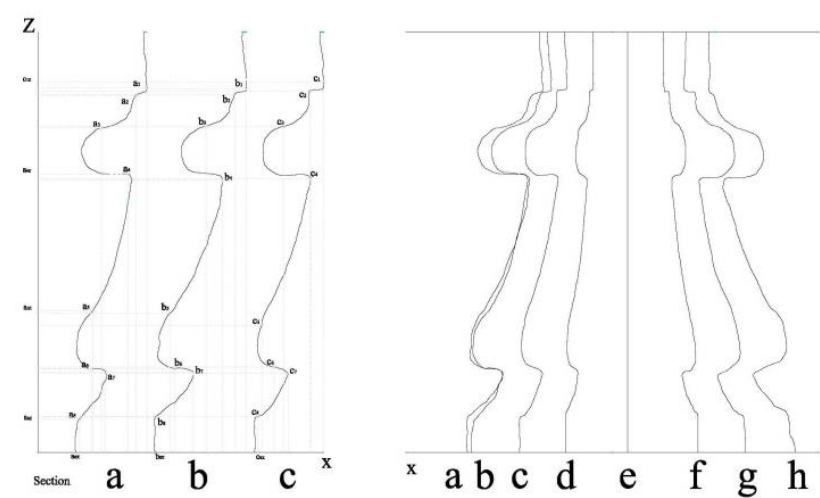

Figure 4. Sections and characteristic points

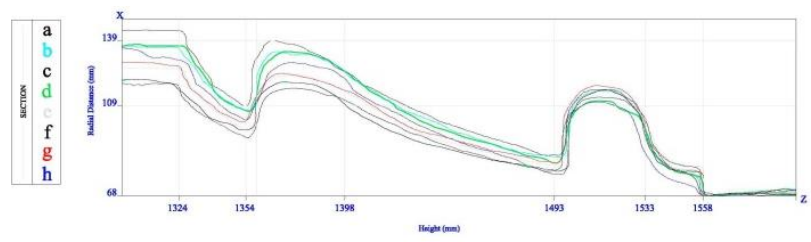

Figure 5. Section comparison

\subsection{Data processing}

Algorithms for the alignment, fusion, definition, correction, and cleaning of the meshes from OS were performed by means of Artec Studio. In addition, the resulting meshes were textured so as to obtain a more representative $3 \mathrm{D}$ model for each case.

The selected elements were sectioned in Rhinoceros software by means of vertical and horizontal planes, following the same criterion and direction in both cases (Cathedral of Seville and Church of Santiago). The cutting panes were place by the vertical edges and half the face of each element (Figure 6).

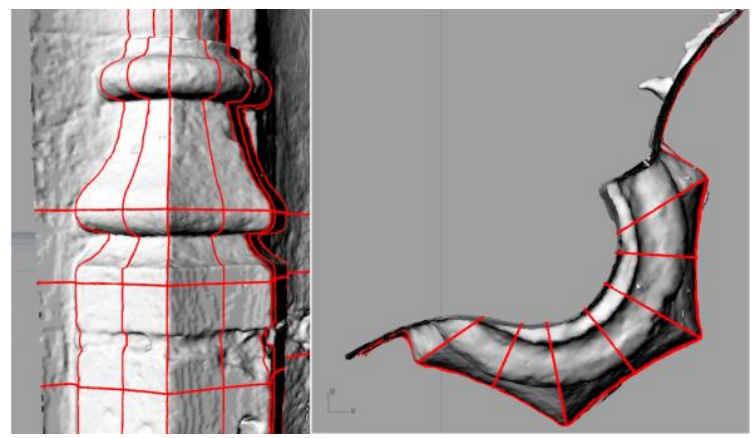

Figure 6. Sections in meshes

In this way, the resulting curves were exported in vector format; likewise the coordinates of the characteristic points were extracted for later mathematical analysis.
In order to ease the graphical comprehension of the data, the global point clouds of both pillars from TLS were imported into ArchiCAD () v20 software as parametric objects. Once the OS meshes were aligned with these pillars, the models are shown to verify the great difference in proportion between pillars of each church (Figure 7).

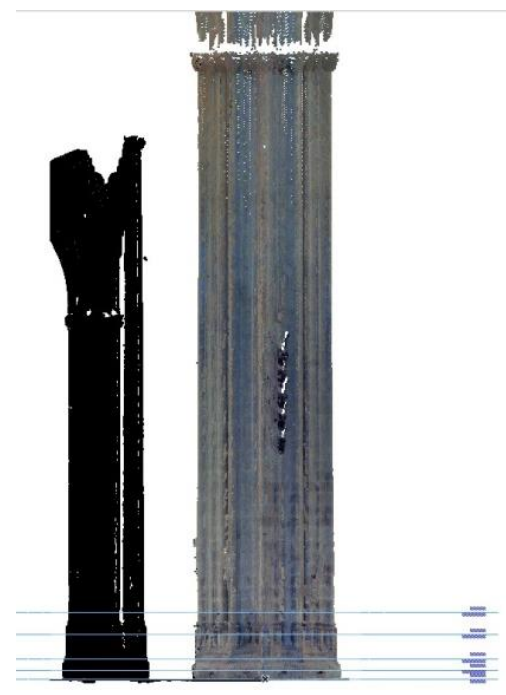

Figure 7. Proportions between the Church of Santiago (left) and the Cathedral of Seville (right)

In the elevation in Figure 8 the levels $+0.55,+1.20$ and $+1.80 \mathrm{~m}$ show the sections of the pillars, which are displayed in Figure 9, 10 and 11.

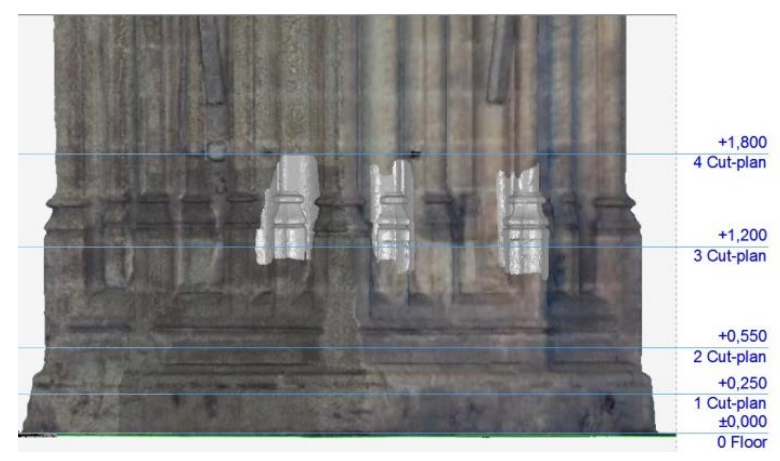

Figure 8. Elevation of the pillar (Cathedral of Seville) with sections

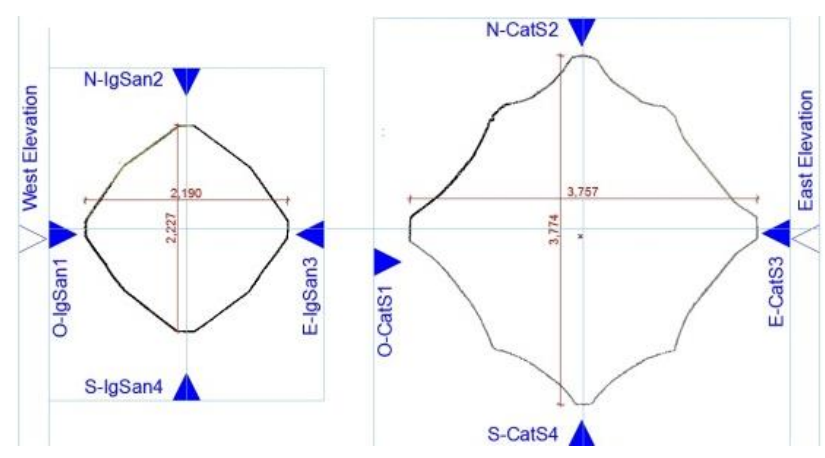

Figure 9. $+0.55 \mathrm{~m}$ sections of the pillars: the Church of Santiago (left) and the Cathedral of Seville (right) 


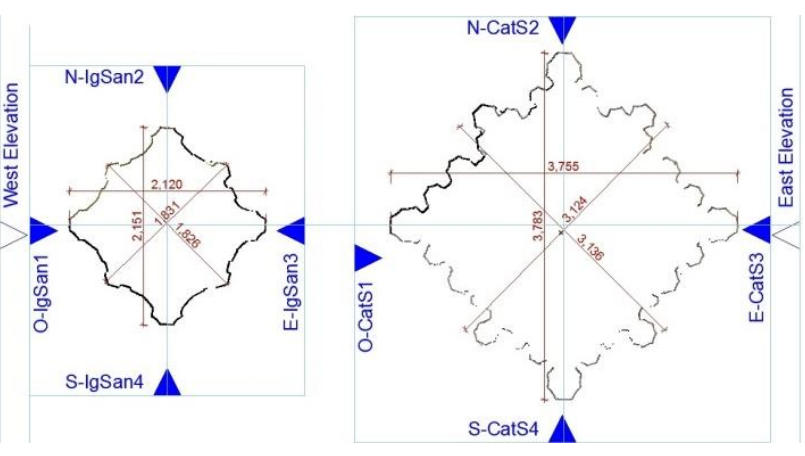

Figure 10. $+1.20 \mathrm{~m}$ sections of the pillars: the Church of Santiago (left) and the Cathedral of Seville (right)

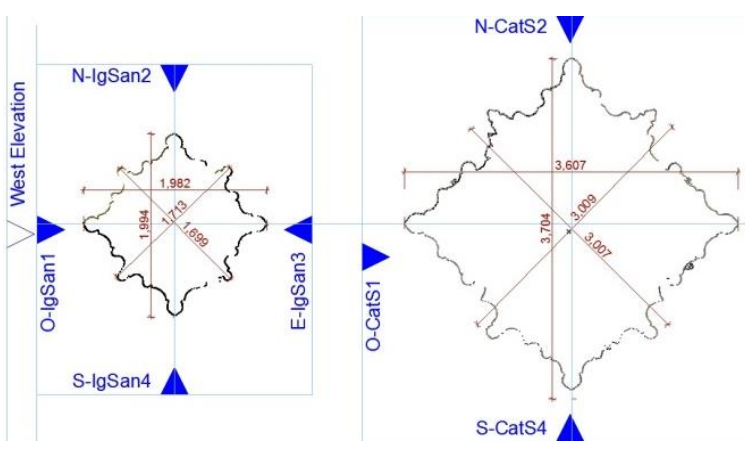

Figure 11. $+1.80 \mathrm{~m}$ sections of the pillars: the Church of Santiago (left) and the Cathedral of Seville (right)

Although the prior sections differ substantially due to the scale of each pillar, the varied Gothic ornaments maintain a certain degree of similarity.

\subsection{Least squares calculation}

As displayed in Figure 11, an analysis of the shape in elements of both pillars was performed by means of the least squares calculation using the characteristic points of each case (Figure 4). The scale of the abscissa axis was doubled in order to ease comprehension.
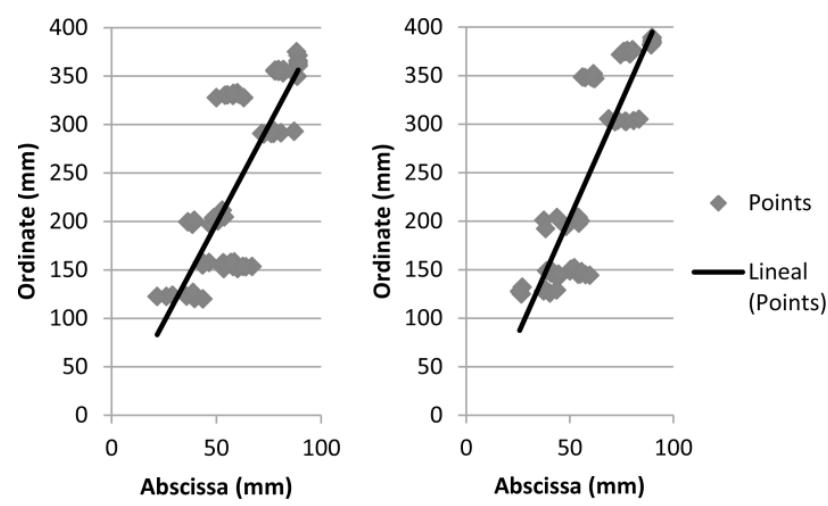

Figure 12. Least squares calculation: the Cathedral of Seville (left) and the Church of Santiago (right)
It is then possible to extract the equations of the characteristic straight lines of each case using the coordinates of the aforementioned points. Being in their slope-intercept form, Equation 1 belongs to the Cathedral, and Equation 2 is related to the Church:

$$
\begin{gathered}
y=4.0541 x-4.9528 \\
y=4.8013 x-36.1750
\end{gathered}
$$

where $y=$ ordinate

$$
x=\text { abscissa }
$$

It can be noticed that the slope of (1) is 4.0541 , with a calculated error of \pm 0.3850 and a coefficient of determination $\left(\mathrm{R}^{2}\right)$ of 0.6414 , whereas the slope in (2) increases. It is 4.8013 \pm 0.3869 , with $\mathrm{R}^{2}=0.7404$.

For its part, the surface of the average section for each pillar is calculated in Table 13 by weighting the areas of the sections:

\begin{tabular}{|l|c|l|c|}
\hline \multicolumn{2}{|c|}{ Cathedral of Seville } & \multicolumn{2}{c|}{ Church of Santiago } \\
\hline Section & Surface $\left(\mathrm{mm}^{2}\right)$ & Section & Surface $\left(\mathrm{mm}^{2}\right)$ \\
\hline a & $13,272.0358$ & a & $12,786.5723$ \\
b & $16,513.4793$ & b & $17,018.1181$ \\
c & $11,961.9487$ & c & $12,998.5149$ \\
d & $15,211.0598$ & d & $16,934.0551$ \\
e & $13,440.1716$ & e & $14,018.1467$ \\
f & $17,237.1329$ & f & $17,558.7135$ \\
g & $14,308.2748$ & g & $14,236.8898$ \\
h & $13,232.1326$ & \multicolumn{2}{|c|}{} \\
\hline Average & $14,397.0294$ & Average & $15,078.7158$ \\
\hline \multicolumn{4}{|c|}{ Table 13. Section surfaces } \\
\hline \multicolumn{4}{|c|}{}
\end{tabular}

Odd sections (a, c, e, g) and even sections (b, d, f) follow the same tendency in each pillar, inasmuch as the sections of the elements were performed by the vertical edges and half the face (see section 4.2, Figure 6).

As a result, the geometrical similarity between elements of both historical buildings derives from the previous two indicators proposed (slope of the characteristic straight lines and average section surfaces).

\section{CONCLUSIONS}

The use of data acquisition techniques such as TLS, OS, and SFM shows numerous advantages to evidence documentary sources in architectural heritage. Based on this kind of sources, this paper proposes a novel approach for the search of a geometrical similarity pattern to support hypotheses initially endorsed by documentary sources.

Using the aforementioned techniques -SFM was not analysed in this paper- this research focuses in detail on architectural elements of pillars of the XV and XVI centuries. Once diverse software was used to align the OS meshes according to the global point clouds from TLS, the different sections extracted show diverse alterations produced by natural processes and the course of time, or possible structural movements, although the parishioners may have also contributed to this geometrical deterioration of the stone. These dimensional incoherencies are perceptible by the naked eye, thus making the authors consider the possibility that the column bases were carved in situ or before their placement. In this sense, it is evident that the 
carvings by the stonemasons were made by hand. However, some alterations in the elements may have been produced by the own signature of the stonemasons. The speed of construction of the Cathedral of Seville can justify this hypothesis of the intervention of several stonemasons at the beginning of the works. The actual geometry of the stone can have several mathematical interpretations allowing new scientific approaches, but these shapes are basically solved with simple geometry based on tangency of circumferences and correctly aligned ellipses. Then the real pattern of the stonemasons is copied through the wooden and cardboard templates that the stonemason defines.

The importance of this research lies in establishing a series of characteristic points of historical elements whose authorship is accurately known in order to compare them with patterns of other objects. These points have been established according to the criteria of the current stonemasons. Here, two key aspects are considered: on the one hand, the metric standpoint; on the other hand, historical-graphical features of the 3D models: composition, techniques, styles, and historical-graphical documentary sources. Thus, the mere dimensional analysis is put aside. For its part, the difference in scale between the buildings studied is proved by the elevations and cross sections provided, and it must be taken into account. Nevertheless, the outcomes of this research -mathematical data and surfacereveal the geometrical similarity between the elements studied. The least squares calculation provides an objective estimation of the variability of the geometry in architectural heritage.

It is also possible to advance on this proposal by studying the sections of the ashlar in the lower parts of the column bases. In addition, other lines of research can be opened as regards analyses in detail of the signature of different stonemasons in order to identify similarities between other historical buildings.

\section{ACKNOWLEDGEMENTS}

This work has been funded by the V Research Plan (VPPI) of the University of Seville. Special thanks to Emilio Yanes Bustamante, architect-director of the works in the Church of Santiago in Jerez de la Frontera (Cádiz, Spain) and Jaime Navarro Casas, architect at the Cathedral of Seville. Thanks to Margarita López, co-ordinator of activities and protocols of the Cathedral of Seville; and Miguel de los Reyes Rincón, from the Spanish firm RESTAURACIONES CANTONAR S.L.

\section{REFERENCES}

Almagro, A., 2000. Fotogrametría para arquitectos. El estado de la cuestión. Actas del VIII Congreso de Expresión Gráfica Arquitectónica. EGA, 2000. Barcelona, 2000.

Akca, D., Freeman, M. 2010. Quality assessment of 3D building data. The Photogrammetric Record, 25(December), pp. 339355.

Arias, P., Herráez, J., Lorenzo, H., Ordóñez, C., 2005. Control of structural problems in cultural heritage monuments using close-range photogrammetry and computer methods. Computers and Structures, 83(21-22), pp. 1754-1766.

Cabeza, M., Un, G., Soler, A., Universitat, E., Castellón, J. I. De. 2013. Gothic stonework in the region of maestrazgo . Virtual models of vaulted systems for three.
Calvo López, J., 1999. Las trazas de montea en la fortificación española del Renacimiento. Actas de Las Jornadas Sobre Fortificaciones Modernas Y Contemporáneas, 41-48.

Calvo, J., Taín, M., Rodríguez, A., Camiruaga, I., 2015. Métodos de documentación, análisis y conservación de trazados arquitectónicos a tamaño natural, Arqueología de la Arquitectura, 12. pp 2-9.

Capilla Tamborero, E., J., 2016. Hipótesis de métodos geométricos en perfiles de dovelas de bóvedas de crucería del Monasterio de Santa María de la Valldigna (Valencia). In: XIII Congreso Internacional Expresión Gráfica aplicada a la Edificación, Castellón de la Plana, Spain, pp. 169-170.

Caramazana, D. and Romero, M., 2016. Cardenal, D. E. L., Hurtado, D., Góticas Gaditanas "El patrocinio new contributions to "las portadas góticas gaditanas ": The Sponsorchip of the Cardinal, Laboratorio de arte 28(2016), pp. 41-59.

Díaz, E. R., 2005. Construcción de una bóveda de crucería en el Centro de los Oficios de León. Historia, pp. 27-29.

Dos Santos, D. R., Dal Poz, A. P., Khoshelham, K. 2013. Indirect Georeferencing of Terrestrial Laser Scanning Data using Control Lines. The Photogrammetric Record, 28(143), pp. 276-292.

Falcón, T., (Ed.) 1984. "El edificio gótico". En La Catedral de Sevilla. Sevilla.

Herrera Gómez, B., Samper Sosa, A., 2014: Sobre la fractalidad de los rosetones góticos. Proc. XII Congreso Internacional de Expresión Gráfica Aplicada a la Edificación, Madrid, Spain, Vol. 2, pp. 558-571.

Koutsoudis, A., Ioannakis, G., Arnaoutoglou, F., Pavlidis, G., Chamzas, C., 2014. Multi-image 3D reconstruction data evaluation, 15, pp. 73-79.

López Mozo, A., Rabasa Díaz, E., Sobrino González, M. 2011. La línea en el control material de la forma. In: Actas Del Séptimo Congreso Nacional de Historia de La Construcción, Santiago de Compostela, 26-29 Octubre, pp. 743-754.

Molina Gaitán, J. C., Goicoechez Acosta, A. 2011. Identificación de útiles de cantería a través de las trazas y marcas de cantero en el primer cuerpo de la catedral de Murcia. In: Actas Del Séptimo Congreso Nacional de Historia de La Construcción, Santiago de Compostela, 26-29 Octubre, pp. 937-946.

Mostaza, T., Julio, P. J., Jimeno, Z., López, J., Artemio, Q., Tejera, M. (n.d.). YAcimientos a Rqueológicos, (1), pp. 403408.

Nieto Julián, J. E., Moyano Campos, J. J., Fernández Valderrama, P., 2014: Implementación de las nuevas técnicas de levantamiento en el sistema BIM (Building Information Modeling). Proc. XII Congreso Internacional de Expresión Gráfica Aplicada a la Edificación, Madrid, Spain, Vol. 1, pp. 318-328.

Ortiz de Zuñiga 1895. Anales eclesiasticos y seculares de la muy noble y muy leal ciudad de Sevilla ... que contienen sus 
mas principales memorias desde el año de $1246 \ldots$ hasta el de 1671.

Pieraccini, M., Guidi, G., Atzeni, C. 2001. 3D digitizing of cultural heritage. Journal of Cultural Heritage, 2(1), pp. 63-70.

Pintus, R., Pal, K., Yang, Y., Weyrich, T., Gobbetti, E., Rushmeier, H., 2016. A Survey of Geometric Analysis in Cultural Heritage, 35(1), pp. 4-31.

Pavlidis, G., Koutsoudis, A., Arnaoutoglou, F., Tsioukas, V., Chamzas, C., 2007. Methods for 3D digitization of cultural heritage. Journal of cultural heritage, 8(1), pp. 93-98.

Pérez García, J. L., Mozas Calvache, A. T., Cardenal Escarcena, F. J., López Arenas, A. 2011. Fotogrametría de bajo coste para la modelización de edificios históricos TT - Low-cost photogrammetry for the modeling of historic buildings. Virtual Archaeology Review, 2(3), pp. 121-125.

Presas i Puig, A. 1997. Un ejemplo de la geometría práctica del gótico: el"Büchlein der Fialen Gerechtigkeit" y la "Geometria deutsch" de Matthäus Rorizcer. Llull: Revista de La Sociedad Española de Historia de las Ciencias y de las Técnicas, 20(38), pp. 239-272.

Rabasa, E. R., 1994. Los arcos oblicuos en la traza de cantería. EGA, pp. 145-152.

Rabasa, E. R., 2005. Construcción de una bóveda de crucería en el Centro de los Oficios de León. Historia,27-29. pp. 909-917.

Remondino, F., Pizzo, S. Del, Kersten, T. P., Troisi, S., Metrology, O., Kessler, B., Fbk, F., 2012. Low-cost and OpenSource Solutions for Automated Image Orientation - A Critical Overview, 40-54

Reu, J. De, Plets, G., Verhoeven, G., Smedt, P. De, Bats, M., Cherretté, B., ... Meirvenne, M. Van., 2013. Towards a threedimensional cost-effective registration of the archaeological heritage. Journal of Archaeological Science, 40(2), pp. 11081121.

Rosa, J. A., (Ed.) 1987. Traza y Simetría de la Arquitectura. En la Antigüedad y Medievo. Sevilla.

Rosa, J. A., 2006. «Dibujos de ejecución. Valor documental y vías de conocimientos de la catedral de Sevilla ». En La catedral gótica de Sevilla. Fundación y fábrica de la obra nueva, pp. 296-347.

Rosa, J. A. R. De, Estévez, J. C. R., 2011. Capilla redonda en buelta redonda: nuevas aportaciones sobre una montea renacentista en la Catedral de Sevilla. In: Actas Del Séptimo Congreso Nacional de Historia de La Construcción, Santiago de Compostela, 26-29 Octubre, pp. 1275-1282.

Teza, G., Pesci, A., Ninfo, A., 2016. Morphological Analysis for Architectural Applications: Comparison between Laser Scanning and Structure-from-Motion Photogrammetry. Journal of Surveying Engineering. pp. 1-10.

Salas, J., 1996. Geometría y función estructural en cantería. La cantería y la estereotomía de la piedra en el aprendizaje del arte de construir y otras consideraciones. Actas Del Primer Congreso Nacional de Historia de La Construcción, 19-21 Septiembre, pp. 189-196.
Sancho De Sopranis, H. (1934). Introducción al estudio de la arquitectura en Xerez. Jerez, Guion. pp. 11-12.

Vallejo, E. M. 2015. Vestigios góticos en la literatura arquitectónica del barroco, Revista anual de Historia del Arte, pp.21-33.

Westoby, M. J., Brasington, J., Glasser, N. F., Hambrey, M. J., Reynolds, J. M. (2012). Geomorphology " Structure-fromMotion" photogrammetry: A low-cost, effective tool for geoscience applications. Geomorphology, 179, 300-314.

Yastikli, N., 2007. Documentation of cultural heritage using digital photogrammetry and laser scanning. Journal of Cultural Heritage, 8(4), 423-427.

Yilmaz, H. M., Yakar, M., Gulec, S. A., Dulgerler, O. N. 2007. Importance of digital close-range photogrammetry in documentation of cultural heritage. Journal of Cultural Heritage, 8(4), pp. 428-433. 